\title{
Study on idle land in China's rural areas
}

\author{
Yunshu Li \\ School of Public Administration, Southwest Jiaotong University, \\ Chengdu, Sichuan, China \\ 515558030@qq.com \\ Yunshu Li
}

\begin{abstract}
For the current situation that there is a large number of idle lands in China's rural areas, this paper puts forward that under the depth analysis of the detriments and reasons of the Idle land in rural areas, we need to endow rural village collectives with greater power, especially for the rights of disposal of idle land and other measures while solving the issue of idle land in rural areas, so that we can make the full and reasonable use of rural land helping to obtain the sustained and stable development of rural economy.
\end{abstract}

Keywords: rural area, idle land, rural collective.

\section{中国农村闲置土地问题的研究分析 \\ 李云舒 \\ 西南交通大学公共管理学院, 成都, 四川, 中国 \\ 515558030@qq.com}

中文摘要. 针对当前中国农村存在着大量 的闲置土地的情况, 本文通过对农村闲置土 地的危害及其原因的深入分析, 提出了需要 通过赋予农村村社集体更大的权力, 特别是 对于农村闲置土地的处理权力等措施来解 决农村闲置土地的问题, 以使农村土地得到 充分、合理的利用, 使农村经济能够得到持 续稳定的发展。

\section{关键词: 农村; 闲置土地; 农村集体}

\section{1. 引言}

土地是人类生存与发展所必需依附的 物质基础, 同时也是一种有限而不可再生的
资源。农村土地作为国民经济基础的第一产 业的基础, 就更显重要与珍贵。中国是一个 农业大国, 虽幅员辽阔, 但是丘陵山地居多, 因而能够得到有效利用的农村土地其实并 不是很多, 加上中国人口基数非常庞大, 在 人均意义上的农村土地就更显不足了。再 者, 改革开放30多年来, 随着经济社会的快 速发展, 中国的城镇化也有了巨大的进步, 而且还将在今后很长一段时间处于快速发 展的通道上, 但是城镇化的发展必然要求占 用更多的农村土地, 这肯定会造成原本就以 人多地少, 后备资源不足为基本国情的中国 严峻的农村土地形势雪上加霜。然而, 就是 在这样一种土地资源严重短缺且有愈演愈 烈之势的情况下, 却在全国范围特别是比较 偏远的地方或山区, 出现农村土地大量闲置 
的现象, 而且闲置比率有逐年提升的苗头。 农村土地闲置是一个不容忽视、亟待解决的 重大问题, 因为土地的闲置, 不仅会恶化它 的自然状况, 弱化其生产能力, 降低农业的 生产率, 而且还意味土地资源没有得到有效 合理地利用, 会加深人地矛盾, 更会影响农 村社会经济的可持续发展, 进一步还会影响 到国家的粮食、农业安全等战略性问题。

\section{2. 农村闲置土地的现状}

以笔者的家乡, 湖南南部的一个普通丘 陵农村为例: 劳动力的大量外流, 使得村庄 只有少数留守的老人和小孩, 这些村民因为 他们有限的生产劳作能力, 只能是种上一小 块菜地供日常食用, 其余土地, 无论是水田 还是菜地, 都只能荒废闲置着。而纵观附近 的各村落, 也大体是这种情况, 人口大量外 流, 土地大量抛荒, 浪费极其严重。而且除 了耕地外, 以宅基地为代表的非农用地也是 浪费严重, 外流的人口中多数都已在城镇购 有房产, 且大多有着固定的工作或者做着稳 定的生意。他们生活已经与农业、农村几乎 没有什么联系了, 但是他们在农村的房子还 在空置, 他们承包的土地还在抛荒。这种农 村土地大量闲置的情况在当地是非常普遍 的。

贵州大学的邵代兴曾到贵州省部分地 区调查发现：松桃县瓦溪乡十字村龙塘湾 组闲置撂荒的旱地面积达 $21 \mathrm{hm} 2$, 闲置撂荒 的水田面积为 $11 \mathrm{hm} 2$; 情况相似的该村苦竹 坪组, 闲置撂荒的耕地更多。在黎平县洪州 镇阳朝村因各种原因闲置的旱地占该村旱 地面积的 $30 \%$ 左右, 水田占 $20 \%$ 左右。在三 穗县长吉乡长吉街上 $80 \%$ 农户旱地全部闲 置, $30 \%$ 水田闲置; 在长吉乡的偏远山村半 坡村, 每户都有劳动力外出务工导致大面积 土地无劳动力耕种。在桐梓县的天坪乡每个 村都有因婚丧等而闲置的土地。在关岭县板 贵乡的每个村都有农户因逃避计划生育导 致土地没有人耕种而闲置。贵阳市花溪区农 村因农民到周边城镇打工而造成土地粗放 经营的农户占 $2 / 3$ 以上。在山区由于历史、 文化、经济的原因还出现大量旧宅基地、旧 房地被闲置而没有利用。据统计, 在桐梓县 每个村旧宅闲置土地至少有 $1 \mathrm{hm} 2$ 之多, 据
此推算全县合计高达 $360 \mathrm{hm} 2$ 。山区季节性 (冬季) 闲置的土地广泛存在，90\%以上农 户冬季都有闲置土地, 70\%以上甚至全部空 闲。

另据 2011 年新华网转发的《国际先驱 导报》关于农民弃种、耕地撂荒的深度报道 显示, 中国每年近 200 万 $\mathrm{hm} 2$ 耕地的撂荒。

而由西南财大和农业银行共同发布的 《中国农村家庭金融发展报告2014》显示, 2013年全国农用地当中有 $15 \%$ 是闲置的, 造 成严重浪费。而2011年该数据为 $13.5 \%$ 。同 时与 2011年相比, 2013年中国土地闲置家庭 占比与土地闲置面积占全国总面积的比重 都分别上升了 1.5 个百分点, 农业土地的闲 置率与闲置面积也在增加。

\section{3. 农村土地闲置的危害}

土地闲置抛荒不仅使得土地资源得不 到有效利用, 还影响土地的质量, 因为土地 停止了农业生产后, 就不能得到有效的打 理, 田土的抗蚀能力逐渐减弱, 土壤物理性 质变差, 因而降低其生态作用, 还会对周边 土地会产生负的外部性。而且荒草丛生后, 这些土地也往往就成了劣鼠害虫的欢乐园, 这些荒草鼠虫也必然会影响周边土地农作 物。这都会给农业生产带来负面效果, 也就 不可避免地会减少农民的经济收入。由于农 村经济收入减少, 农村集体公益事业也会受 到严重影响, 农村的生产条件也就无法改 善, 这又间接地加重了农民的负担, 从而影 响整个农村经济的发展和农村生活水平的 提高。

大量农村土地闲置使本来人均耕地就 少的矛盾日益加剧, 再加上近些年农民种粮 的积极性越来越低、农业生产长期粗放经 营, 而且全球范围的极端天气又频繁发生, 造成各种天灾，因此粮食的收成因种植面积 缩水而降低, 加上扣除自然灾害的损失, 肯 定会面临着很大的减产压力。然而, 随着中 国经济的快速发展, 对农产品的需求却是有 增无减, 因此导致农产品价格上涨, 恶化了 农产品供需矛盾, 这在很大程度上会威胁到 中国的粮食安全。

中国以不到世界 $10 \%$ 的耕地, 养活了 世界 $22 \%$ 的人口，可见中国耕地资源的承 
载压力是巨大的。目前耕地资源短缺的矛盾 越来越突出, 已经影响到经济的可持续发 展。今后一个相当长的时期, 中国人口将继 续增加, 人地矛盾将更加突出。可持续发展 唯一的出路就是用好管好有限的土地资源, 不容土地闲置。

\section{4. 农村土地闲置的原因}

国内经济快速发展, 城镇化进程高速推 进, 再加上农业生产的经济环境、政策环境 和自然环境、社会环境等的不利因素, 使得 农业生产的比较收益较低, 农民的农业生产 积极性不高, 降低了对土地的依赖, 大量农 村剩余劳动力涌入城市, 因而造成了当前大 量农村土地闲置的现象。

\section{1 经济原因分析}

自家庭联产承包责任制释放了农村经 济的巨大活力后, 农业发展就进入了一个稳 定的节奏, 然而随着经济社会的发展, 农业 生产的成本开始上升, 从基础的种子、化肥 农药和机械设备等农资价格到人工费用等, 都有了大幅的上涨; 而且之前村社集体提供 排灌、道路等公共物品, 现在要由单家独户 自行解决, 无疑又增加了生产的成本, 而粮 食等农产品价格的上涨幅度却十分有限, 而 且农业越丰收, 其价格反而越低。再加上不 可预测的自然灾害对农业收成的不利影响。 因此农业生产的利润不仅没有得到提升, 反 而有所减少。再者随着工业化与城市化的发 展, 城市对劳动力的需求越来越大, 并且到 城市就业所能获得的收入远远高于在农村 从事农业生产所能得到的收入, 因此大量农 村劳动力从农村流向东南沿海等发达地区 或经济比较活跃的城市, 导致农村劳动力不 足, 土地大量闲置, 造成了土地资源的严重 浪费。另外, 在经济社会的发展过程中, 很 多农村人通过自己的勤奋工作、辛勤劳动或 者合法经营而致富, 实现了他们的城市化, 他们的一切生活都由农村迁移到了城镇, 但 却仍然保留着原来承包的土地和房产而无 人耕种与居住, 造成农用地与宅基地的闲 置。即使是那些没能实现城市化的外流劳动 力, 因为平时的工作生活主要在城市, 他们
自己承包的土地也就长期处于闲置状态, 成 为了闲置土地。

\section{2 制度原因分析}

家庭联产承包责任制虽然取得了很多 的成效，但是产权主体不明，新时期农村的 生产方式仍处于小农状态, 分散经营, 生产 效率低下，农民的收入不高，农业生产处于 缓慢发展状态。随着近些年各种农业政策赋 予了农民更多的土地权利，而把农村集体的 权利基本取消了, 因而没有了集体指挥决定 权, 很多农村的土地流转与规模经营因为

“搭便车” 现象的存在而困难重重, 这在一 定程度上也助长了土地闲置情况的发生。由 于集体所有者身份的名存实亡, 使得农村基 础设施建设, 特别是与农业生产有关的农田 水利方面的建设几乎处于停滞状态。农业作 为一个抵抗风险能力较差的产业, 除了受政 策风险和市场风险的制约之外, 还受环境风 险的制约。农村基础设施与农田水利设施的 状况直接影响到农民农业生产的收益, 农民 种地若不能旱涝保收, 他们种地的积极性肯 定会受到影响。再者一些农村土地因权属纠 纷长期得不到解决, 而致无人开剭而使土地 闲置。

\section{3 其它原因分析}

社会一直存在着轻视、看不起农民的观 念, 因而大部分有点知识、有点文化的青年 农民都不愿意留在农村从事农业生产活动。 而且改革开放后, 中国城乡差距逐渐扩大, 农村人心理上越来越难以承受, 因此许多农 村人都想方设法地往城里走, 不愿意呆在农 村。有的农村人则受封建迷信的影响, 修建 了新房却闲置着旧的宅基地, 造成大量旧宅 基地、旧房地被闲置。还有的农户因婚丧嫁 娶等原因导致地多人少, 无力耕种; 另一些 农民为逃避计划生育政策的惩罚长期在外, 自己的土地无人耕种而闲置; 此外, 一些农 村用地被工程，如修路、采石、厂矿等临时 占用一定时间或者破坏后处于闲置状态; 再 者, 很多的土地退耕还林后, 由于无人管理, 树木成活率低, 因而变成荒地。 


\section{5. 解决农村土地闲置问题的建议}

\section{1 完善政策制度方面}

加大对农业的扶持力度, 落实好惠农政 策。加强农村地区的基层组织领导, 加大农 业种植的宣传力度, 落实好水稻良种和农机 具购置补贴等各项惠农政策, 政府应该进一 步给予政策上的鼓励, 比如提高农业生产 的直补, 农资综合补贴等, 切切实实提高农 民从事农业生产的收益, 提高农民从事农业 生产的积极性。

完善土地流转制度。为了加强对农村闲 置土地的合理利用, 可以采取自由流转、出 租等的方式进行处理。同时, 政府特别是基 层政府不要对农村闲置土地的承包或者流 转进行干预, 也不承担风险与责任, 但是需 要制定一系列的规章制度, 以确保土地流转 健康合理的进行, 并对农村闲置土地的转 让、出租等信息进行及时的公布, 使闲置土 地能在更大的范围得到最大限度的合理有 效利用。

赋予农村集体在发展农业方面比较大 的权力。农村大量闲置土地的出现, 与农村 村社集体权力的消失是不无关系的。在当前 的情况下, 农民几乎不可能仅仅凭借单家独 户来完成农业生产所需要的基础条件, 如果 村庄集体继续被抛弃, 农户的生产条件就会 进一步恶化, 无论是农田排灌、土地整治, 还是土壤改良、机耕道路和农田林网等建设 就很难有效率地进行, 农民的生产就会停留 在高投入、高风险、低回报的困境。给予农 村集体农业方面更大的权力, 特别是对于农 户承包土地的回收与再分配权利, 不仅能为 农业生产提供更好地基础条件, 降低单个农 户农业生产的成本, 还有权利合理地处理闲 置土地, 使这些闲置的土地得到更好地利 用。比如对于常年在外工作的农民工的个人 闲置土地、荒芜基本农田和集体闲置土地 等, 按照相关规定收回它们使用权, 重新划 入基本农田保护区等。而对于已经在城市稳 定生活工作且已购房者来说, 除按照规定收 回闲置土地使用权外, 还应该收回其宅基地 的使用权。如果这些人将来又重新回到农村 生活生产的话, 则村社集体应该也有义务和 权利重新分配他们合理的土地及土地权利 和义务。这样, 不管农民个人或者家庭是生
活在城市还是农村, 他们承包的这些土地都 能得到有效利用, 而不至于闲置浪费。

\section{2 改善农业生产方面}

建立和健全农业生产服务体系。改善农 村的投资环境，提高农民的劳动生产率，从 而提高农民的经济效益, 吸引农民从事农业 生产活动, 减少土地闲置面积。加强农业基 础设施建设, 特别是具有公共物品性质方面 的基础设施建设, 以降低农业生产成本, 增 强农业抵抗自然风险的能力。比如农田水利 工程, 以满足现代农业防洪、防旱和灌溉的 需要。积极发展节水农业, 像各种小型拦蓄 水工程、引水工程、农田机井和各种节水灌 溉工程等, 推动农村基础设施建设, 增强农 民抗御风险的能力, 确保农业生产的安全和 农民农业生产情绪的稳定, 达到旱涝保收, 稳产高产。结合新农村建设、农业综合开发, 消除交通 “瓶颈” 现象, 加强农村与农村、 农村与城市之间的联系, 改善农村和农业生 活生产条件。

加强科技服务体系建设, 改进农业科技 的指导方法。要实现农业的高产，提高农民 从事农业生产的积极性, 政府必须加大对农 业特别是种粮科技的投入力度。农业技术推 广部门要加强对基层技术推广人员的培训, 提高技术推广人员的整体素质与技术水平, 以促进现代农业的高效发展。

运用市场手段调节与农业生产相关的 产品价格, 降低农资价格。通过市场手段、 价格工具, 调节农民对经济作物的偏好, 根 据本地区的特点, 扬长避短, 发挥土地本身 的优势, 积极引导、调整农民的种植结构。 政府通过制定相应的措施，加强对化肥、农 药等涉农生产企业和农资市场的监管, 降低 农业生产资料的价格, 减少农业生产成本。

优化农业生产结构与区域布局。合理地 规划调整农业生产结构与布局, 在提高土地 产出率的基础上, 协调好产业结构与区域分 布，避免 “谷贱伤农” 及类似情况的发生， 调动农民对农业生产的积极性。加强农村信 息网络和品牌的建设, 让农民及时准确地掌 握农产品市场信息, 拓展农产品销售渠道, 提高农产品的附加值。 


\section{6. 结束语}

总之, 我们要树立科学的土地利用观和 管理观, 深入分析当前农村土地闲置的原 因, 盘活闲置土地, 经营好闲置土地。做到 科学合理地利用土地, 规范土地市场秩序, 完善土地资源合理配置机制, 科学合理地 利用土地, 充分提高土地的使用效益, 做 好农村闲置土地的开发与利用工作, 促进农 村闲置土地的充分利用, 增加耕地面积, 促 进农村经济的发展。为中国农业现代化的健 康快速发展提供土地支撑。

\section{References}

[1] Yunling Liu, Study on Intensive Management of Rural Land, Journal of Shanxi Agricultural Sciences, vol 36(6).pp 11-12, 2008
[2] Daixing Hao,Tengbing $\mathrm{He}$, The exploitation and utilization of idle lands resources in the mountain area, Journal of Mountain Agriculture and Biology,vol.2, pp 146-150,2007

[3] Jingjing Duan, Kun Zhang, Analysis of the reasons and countermeasures for currently idle land, Rural Economy and Science-Technology.vol.4, 2014

[4] Yingqun Lu, Jiannan Duan, Research on the reasons for rural idle land, Land \& Resources Herald, vol.2, pp.56-58, 2014

[5] Yueli Wang, Discussion on the reasons and solutions for the rural land idle, New Countryside, vol.20, 2012

[6] Meixia Su, The status and utilization of idle land in rural area, Science and technology of Sichuan Agriculture, vol.11, 2013 